\title{
NOTES
}

\section{Antigenic Scheme for the Hafniae}

\author{
A. P. BATURO AND V. P. RAGINSKAYA \\ Mechnikov Research Institute for Vaccines and Sera, Moscow, U.S.S.R.
}

The role of opportunistic pathogens in infectious pathological conditions of humans is increasingly being appreciated. Some organisms that have been considered nonpathogenic occasionally cause severe hospital infections and outbreaks of acute enteric diseases.

Although considered to be a commensal inhabitant of the intestinal tract (6), Hafnia alvei (syn. Enterobacter hafniae) has been reported to cause acute enteric diseases, urogenital inflammatory conditions, septic poisoning, and other diseases $(1,3,4,8,9)$.

During the past several years, a study of biochemical and antigenic properties of $303 \mathrm{H}$. alvei strains was carried out in the Laboratory of Opportunistic Enteric Pathogens at the Mechnikov Research Institute for Vaccines and Sera, Moscow. One hundred and sixty-seven of the Hafnia strains used in this study were isolated from enteric patients or were obtained from other sources in the U.S.S.R.; other strains were kindly supplied by L. Le Minor (Paris, France), P. Carpenter (England), J. Kiesewalter (G.D.R.), and K. Lachowicz (Warsaw, Poland).

All of these strains had similar enzymatic properties and could be identified as members of $H$. alvei by their phenotypic characteristics. For the serological grouping of these strains by antigen type, $92 \mathrm{O}$ antisera and $37 \mathrm{OH}$ antisera were prepared from rabbits.

For $\mathrm{O}$ antisera, bacterial suspensions prepared in physiological saline and heated at $100^{\circ} \mathrm{C}$ for $2.5 \mathrm{~h}$ were used as antigens. The rabbits were immunized with four increasingly larger doses of the suspension containing $10^{9}$ cells per $\mathrm{ml}$ as follows: $0.5,1,2$, and $3 \mathrm{ml}$ injected intravenously at 4-day intervals.

$\mathrm{OH}$ antisera were obtained by immunizing rabbits with 6-h-old broth cultures killed with $0.3 \%$ Formalin. To obtain $\mathrm{H}$ antigens, the strains were subcultured several times (up to 10 passages) in $0.3 \%$ agar medium at $25^{\circ} \mathrm{C}$.

The serological grouping of the strains by $O$ antigen was done in the usual way by agglutination and absorption tests (7). If the crossabsorption of agglutinins did not cause a decrease in the titer of homologous antibodies in the antisera, the strains were considered to belong to the corresponding $\mathbf{O}$ groups.

A total of 39 serological $O$ groups was estab- lished by the results of the agglutination and agglutinin absorption tests. In some strains, $\mathrm{O}$ antigens consisted of several partial factors. Thus, the existence of single and double intrageneric antigenic relationships, more or less pronounced, was established. The heterologous antibody titers varied between 1:100 and 1:800.

The grouping of the strains by $\mathrm{H}$ antigen was carried out as described for $\mathrm{O}$ antigens. From the results of the agglutination and agglutinin adsorption tests, 36 varieties of $\mathrm{H}$ antigen were identified. $\mathrm{H}$-antigenic relationships were established, and these were found to be more pronounced than the $\mathrm{O}$-antigenic relationships.

In accordance with the various combinations of $\mathrm{H}$ and $\mathrm{O}$ antigens discovered, the strains tested were found to belong to 57 different serovars. To our regret, the strains used by $R$. Sakazaki (7) and H. Matsumoto (5), in working out the provisional scheme for the differentiation of the hafniae, were not available and thus could not be directly compared with the strains studied here.

From the results obtained from this study, a provisional antigenic and diagnostic scheme for the differentiation of the hafniae was developed. It includes 39 serological 0 groups with 36 varieties of $\mathrm{H}$ antigens, which occur in various combinations. Thus, 57 serovars of the hafniae were recognized. For each specific $\mathrm{H}$ or $\mathrm{O}$ antigen, a corresponding reference strain has been determined. These strains are available from the Laboratory of Opportunistic Enteric Pathogens at the Mechnikov Research Institute for Vaccines and Sera, Moscow. The proposed antigenic scheme (Table 1) provides basic guidelines for the preparation of diagnostic agglutinating antisera, which can be used in the routine work of bacteriology laboratories. We have rather frequently isolated from patients serovars $\mathrm{O} 4: \mathrm{H} 6,7$, O4:H-, O6:H12,13, and O37:H-.

\footnotetext{
We are extremely grateful to the late $P$. Carpenter and to J. Kiesewalter, K. Lachowicz, and L. Le Minor for the Hafnia strains that they kindly sent us.
} 
TABLE 1. Antigenic scheme for the hafniae

\begin{tabular}{|c|c|c|c|c|c|c|c|}
\hline H. alvei strain & O-group & 0 -antigen & H-antigen & H. alvei strain & 0 -group & $\mathrm{O}$-antigen & $\mathrm{H}$-antigen \\
\hline H. alvei & 1 & 1 & 1 & 121 "K" & 20 & 20 & 26,13 \\
\hline PC-32011 & 2 & 2 & 2 & $133^{\prime \prime} \mathrm{K}$ ” & 21 & 21 & \\
\hline $\begin{array}{l}1-65 \\
469 / 64\end{array}$ & 3 & $\begin{array}{l}3 \mathrm{a} 3 \mathrm{~b} \\
3 \mathrm{a} 3 \mathrm{c}\end{array}$ & $\begin{array}{l}3,5 \\
4,5\end{array}$ & $174 “ \mathrm{~K} ”$ & 22 & 22 & 27,19 \\
\hline $\begin{array}{l}12-66 \\
166\end{array}$ & 4 & $\begin{array}{l}4 a 4 b \\
4 a 4 c\end{array}$ & 6,7 & $\begin{array}{l}176 \\
183\end{array}$ & $\begin{array}{l}23 \\
24\end{array}$ & $\begin{array}{l}23 \\
24\end{array}$ & $\begin{array}{l}28,7 \\
29,21\end{array}$ \\
\hline $\begin{array}{l}206 \\
196 \mathrm{~g} / \mathrm{s}\end{array}$ & 5 & $\begin{array}{l}5 a 5 b \\
5 a 5 c\end{array}$ & $\begin{array}{l}8,9 \\
11\end{array}$ & $184^{\prime \prime} \mathrm{K}$ " & 25 & 25 & \\
\hline $21 / 7$ & 6 & 6 & 12,13 & $\begin{array}{l}186 \\
111 \text { “K” }\end{array}$ & $\begin{array}{l}26 \\
27\end{array}$ & $\begin{array}{l}26 \\
27\end{array}$ & 17,7 \\
\hline 203 & 7 & 7 & & 118 & 28 & 28 & 31 \\
\hline $755 / 64$ & 8 & $8,16 c$ & 14,13 & 178 & 29 & 29 & 28,7 \\
\hline $180 / 66$ & 9 & 9 & 15 & $17-66$ & 30 & 30 & 20,21 \\
\hline $2-66$ & 10 & $10 \mathrm{a} 10 \mathrm{~b}$ & $16^{\prime}$ & $19 f$ & 31 & 31 & 20,21 \\
\hline $\begin{array}{l}181 \text { “'K” } \\
47 / 65\end{array}$ & 11 & 11a11b & 17,7 & $773 / 66$ & 32 & 32 & 33 \\
\hline $\begin{array}{l}41 / 00 \\
624\end{array}$ & 12 & $12 \mathrm{a} 12 \mathrm{c}$ & 18,19 & $139-4$ & 33 & 33 & 34 \\
\hline 388 & 13 & $13,10 b$ & 20,21 & $20-2$ & 34 & $34,14 a$ & 1,35 \\
\hline $15 / 2$ & 14 & $14 a 14 b$ & 22 & $\begin{array}{l}\text { WF-3 } \\
23-65\end{array}$ & 35 & $\begin{array}{l}35 a \\
35 a 35 b\end{array}$ & 18,19 \\
\hline $81 / 64$ & 15 & $15,12 b$ & 15 & 76 & 36 & $36 a 36 b$ & 9,10 \\
\hline $\begin{array}{l}602 \\
18-65\end{array}$ & 16 & $\begin{array}{l}16 a 16 b \\
16 a 16 c\end{array}$ & 23 & $240-5$ & 37 & 37 & \\
\hline 2965 & 17 & $17,36 \mathrm{~b}$ & 1,24 & 528 & 38 & 38 & \\
\hline 262 & 18 & $18,11 b$ & 25,13 & $120^{\prime \prime} \mathrm{K}$ ” & 39 & 39 & 36 \\
\hline $\begin{array}{l}8-66 \\
177^{\prime \prime} \mathrm{K} \text { " }\end{array}$ & 19 & $\begin{array}{l}19 a 19 b \\
19 a 19 c\end{array}$ & $\begin{array}{l}17,7 \\
16\end{array}$ & & & & \\
\hline
\end{tabular}

\section{LITERATURE CITED}

1. Baturo, A. P. 1972 . On identification of Hafnia. Lab. Delo 7:430-432.

2. Baturo, A. P., V. P. Raginskaya, and J. Kiesewalter. 1974. Provisional diagnostic scheme of differentiation of Hafnia bacteria by $\mathrm{O}$-antigen. J. Microbiol. (Moscow) 2:103-106.

3. Kalashnikova, G. K., A. K. Lokosova, R. S. Sorokina, A. I. Brodova, A. S. Grivzova, A. P. Baturo, and V. P. Raginskaya. 1974. Concerning the etiological role of Citrobacter and Hafnia in children suffering from diseases accompanied by diarrhea, and some of their epidemiological peculiarities. J. Microbiol. (Moscow) 6:78-81.

4. Kolta, F., and G. Weiner. 1967. Angaben zu der Rolle der Hafnia-Stämme in Enterocolitis-Frkrankungen.
Zentralbl. Bakteriol. Parasitenkd. Infektionskr. Hyg Abt. 1 Ref. 207:413.

5. Matsumoto, H. 1963. Studies on the Hafnia isolated from normal human. Jpn. J. Microbiol. 7:105-114.

6. Richard, C., and J. M. Alonso. 1976. Une enterobactérie méconnue: Enterobacter hafniae. Bull. Inst. Pasteur (Paris) 74:339-352.

7. Sakazaki, R. 1961. Studies on the Hafnia group of Enterobacteriaceae. Jpn. J. Med. Sci. Biol. 14:223-241.

8. Serebrykov, L. W., and W. P. Blochov. 1972. Characterization of acute enteric diseases caused by Hafnis bacteria. Woennij Med. J. 7:60-63.

9. Washington, J. A., R. J. Birk, and R. E. Ritts. 1971 Bacteriologic and epidemiologic characteristics of $E n$ terobacter hafniae and Enterobacter liquefaciens. J. Infect. Dis. 124:379-386. 